\title{
The History of Sharing Video Content in Poland: Analog copies of the 1980s as a Factor of Digital Peer Re-production in the 2000s
}

\author{
PIOTR TOCZYSKI*, MIROSŁAW FILICIAK** \\ * Institute of Philosophy and Sociology, \\ The Maria Grzegorzewske University, \\ ul. Szczésiliwicka 40, 02-353 Warsaw, Poland, \\ E-mail:ptoczyski@aps.edu.pl \\ ** Institute of Cultural Studies, \\ University of Social Sciences and Humanities, \\ ul. Chodakowska 19/31, 03-815 Warsaw, Poland, \\ E-mail:mfiliciak@swps.edu.pl
}

\begin{abstract}
We depict practices of Polish audiences in communist Poland and the transition of these practices after the fall of communism. In Eastern Europe, digital distribution of video content has been built on semi-peripheral culture of VHS tapes copying and sharing. Although the unique Polish 20th century historical trajectory contains the experience of being excluded from Western popular culture, the first decade of 21 st century brought unlimited digital access to audiovisual content. Peer re-production, a non-creative mode of participation increased. Our article provides new historical data illustrating this specificity both in terms of historical experience and globalizing technological progress.

Key words: Poland, file-sharing, peer re-production, video content, TV series, post-network
\end{abstract}


We depict practices of Polish audiences in communist Poland and the transition of these practices after the fall of communism. In Eastern Europe, digital distribution of video content has been built on semi-peripheral culture of VHS tapes copying and sharing. Although the unique Polish 20th century historical trajectory contains the experience of being excluded from Western popular culture, the first decade of 21 st century brought unlimited digital access to audiovisual content. Peer re-production, a non-creative mode of participation increased. Our article provides new historical data illustrating this specificity both in terms of historical experience and globalizing technological progress.

\section{THE RESEARCH PROBLEM AND THE STRUCTURE OF OUR INQUIRY}

When a top global business consulting company was commissioned to support the Polish audiovisual industry with data on the imagined loss through internet "piracy", they made only one assumption: Those who download files, would definitely buy them, and would they have no opportunity to download. To attract media attention, as is usually promised by those who sell such consulting, the report started with two American television series: "Game of Thrones" and "House of Cards". According to anecdotal evidence, Polish internet users seemed to be very active in downloading and sharing those two online television series. They were among the top global populations both downloading and sharing recent American post-network television series, regardless of the source (PWC, 2014). Our question is: what explains such an extent of reproduction noticed at the semi-peripheral corners of the European Web?

This phenomenon can be explained from more than one perspective, combining global and local factors. One such perspective is the American cultural hegemony through internal attractiveness and advertising power. Another is the perspective of global culture flow. These explanations are obvious. The perspective we will hereby examine is the viewpoint of historical experience: country-specific, of national range, local rather than global. We will provide social research data, historical facts and discourse for the years 1980-2010. It will allow us to critically 
illustrate the change trajectories in the practices of Polish audience access to Western culture after 2010. We deliberately limit the scope of this analysis to the beginning of the collapse of communism in Poland (1980) and the first two decades after 1989 (1990-2010). This period marks Poland's transition from communism to a liberal democracy and contributes to the explanations of post-2010 digital media culture phenomena.

The article structure is as follows. Firstly, we present Internet usage as non-creative peer re-production. Secondly, we describe our mixed methods approach. Thirdly, we use our first method (historical) to explain peer re-production in terms of historical experience and confronting discourse with practices. Fourthly, we use our second research method (survey research results) to focus on the specificity of Polish peer re-production. Finally, we theorize the pre-1989 ecology of access to audiovisual content in European semi-peripheries as a factor of the 21 st century informal economy of the media.

\section{INTERNET USAGE AS NON-CREATIVE PEER RE-PRODUCTION}

Although we believe that the boundary between media, consumer and cultural studies is artificial, and results from the academic division of labor (see: Kellner, 2009), it seems that one of the problems of contemporary research in these fields is overstating the importance of creativity in everyday cultural practices. On the one hand, it is a legacy dating back to the 1970s' fantasies about the "new media". It has been fantasized that providing a return channel for customers would revolutionize social life. In this perspective, the current division between senders and recipients would result almost exclusively from access to tools of creating and distributing their own content. However, just as the Internet bandwidth is not what makes an active user, so the ability to create does not make a "creator".

As we limit our area of analysis to the period ending in 2010, the exploration of Polish context at that time (to which we will return later in more detail), showed some creativity-related paradoxicalities. Although more than half of Polish Internet users (58\% male and $49 \%$ female Internet users) declared that they had ever placed a comment somewhere in the network or posted a comment in the message board, only for $8 \%$ users it was a daily activity. Although $17 \%$ Internet users declared writing own blog, only $3 \%$ of bloggers spoke of it as a daily occupation (Toczyski et al., 2011).

Within the iconic Internet sites based on user-generated content most traffic is generated by commercial content - uploaded legally or not. For example, the YouTube user-generated 
content includes only $17.2 \%$ of the most watched videos, while the content posted by partners was more than 43\%, and "pirated" content - almost 35\% (TubeMogul, 2010).

Therefore, a statement of largely creative use of the Web makes sense only if we consider each trace left on the internet a creative work - emoticons placed under the entry on the blog or click on a "like" under the status of a friend on Facebook. But it is hard to resist the impression that the recognition of these activities on par with the creation of their own recordings such as music or video is an abuse and seems to be a new incarnation of cultural populism (McGuigan, 1992). Researchers find too often the subversive potential where in fact the existing relations of power are strengthened (Rafael, 2003). We therefore believe that although the Internet - whether use of this generalizing term may make sense nowadays - has redefined the existing hierarchies of culture and opened an unprecedented degree of public sphere in the bottom-up activity, the majority of Internet users is still a "silent majority." At most they actively consume content provided by professional or amateur publishers or content delivered via a hybrid professionalamateur chain.

According to the Polish writer Jacek Dukaj, the use of the term "pirate" closes the opportunity for exchange of arguments and a real discussion about the informal economy of the media - which is why Dukaj proposes (one needs to add that without much effect) to replace it by another, such as "phreaker" (referring not only to the hacker culture, but also to the Polish tradition of the unauthorized transmission and using the cable television signal (Dukaj 2009).

At the same time, however, the importance attributed to the practices of piracy is changing - which can be seen even in the way of argument by Agnete Haaland, the president of the International Actors' Federation, who said: "We should change the word piracy (...) To me, piracy is something adventurous, it makes you think about Johnny Depp. We all want to be a bit like Johnny Depp. But we're talking about a criminal act" (Shastry 2010). In turn, members of India's Raqs Media Collective, analyzing the exchange of files on P2P networks, presumably following the footsteps of the famous Temporary Autonomous Zone of Hakim Bey, refer to the democratic and subversive tradition of piracy: "Just as the piracy of the past disturbed the equilibrium composed of slavery, indentured labor, the expropriation of the commons, the factory system and penal servitude, the electronic piracy of the present is destined to wreck the culture industry either by making the economic and social costs of policing content prohibitive, or by ushering in a diversity of new protocols of usage, distribution, and reproduction of cultural and intellectual content that will make the whole enterprise of making vast sums of money out of the "nothing" of data and culture a difficult business" (2010: 148). As it can be seen, the 
discourse is not homogeneous. Before we trace its historical transformations in Poland, a few more words about our conceptual apparatus should be said.

As mentioned above, the topic of shifting emphasis between production and redistribution of content in the networked information economy is the conceptual matrix we also designate through the modified ("pirated"?) notions serving the analysis of content over networks. Rethinking online creativity and so called piracy required careful choice of the language of such analysis. We decided to call it 'peer re-production of TV content', with the hyphen directing attention to the non-productive quality of reproduction: ie. re-production as it was named in previous work introducing the concept (Filiciak and Toczyski, 2014).

The interest in online creating coincides with the perception of culture's economic potential and the culturification of economy. It has culminated in the concept of creative industries and treating the society as a resource from which the industry can draw. Such approach is exemplified by ideas of Richard Florida, already criticised (Lovink and Rossiter, 2007). Not denying the emancipatory potential of creative action for the individual, we want to point out that intentional creation is not as important for Internet activity as Internet researchers say, often repeating the slogans of Web 2.0.

The starting point for us is the concept of peer re-production. Yochai Benkler describes the commons-based peer production as a "radically decentralized, collaborative, and nonproprietary; based on sharing resources and outputs among widely distributed, loosely connected individuals who cooperate with each other without relying on either market signals or managerial commands" (2006: 60). In a similar manner, peer re-production works: anonymous Internet users share their resources (disk space, network connections, stored files), exchanging them in a non-hierarchical and out-market mode (Filiciak and Toczyski, 2014).

This definition is best suited for $\mathrm{p} 2 \mathrm{p}$ file-sharing networks. Of course, the inputs of the users are usually incomparably smaller than those involved in cultural production, but the scale of this phenomenon is much greater - the number of people exchanging files on the network is not comparable to the number of people editing Wikipedia or forming Linux. It does not allow one to ignore this phenomenon. Ignoring this would mean adopting the perspective imposed by the creative industries, which are willing to criticize the pirates for the losses incurred by them; however, did not engage in a discussion about the "loss" of users who subsidize Web 2.0 companies providing them with free services, raising the value of their products and services (Terranova 2000), or even reproducing and providing "pieces of content" to generate an increased demand for certain content. In Benkler's perspective, one of the topics relates to the fact that the content is non-proprietary which in relation to piracy cultures shows yet another 
dimension: the lack of possession does not apply here only to rights (which in the case of pirated content are not possessed), but more often the lack of quasi-ownership or quasi-possession increasingly important is just access, and not quasi-ownership or quasi-possession of content.

That means not even downloading the file to the computer, but watching a movie, listening to music or reading a text in the transmission stream using the content provided in one of the web sites by anonymous Internet users. At this point there are intermediaries - sites such as YouTube, which entails the need to introduce yet another category here. We believe that the informal exchange practices of the media cannot be analyzed in terms of simple opposition of the creative industries on the one hand, and on the other hand, user-generated content. All actors in the cultural scene - and there are more, also including technology, law, and often responding to the changes in the software (which was visible in further decentralization of $\mathrm{p} 2 \mathrm{p}$ networks after the trial of Napster), discourses legitimizing or stigmatizing piracy, but also companies providing Internet services and manufacturing equipment - come together in complex relationships. Binary oppositions quickly introduce us to the world of fiction - for example, we might consider that as a result of piracy the users are gaining, and the industry is losing. But even if the manufacturers and distributors of content lose, at the same time the internet service providers' profits grow.

\section{METHODOLOGY}

This analysis is limited to 1980s and the first two decades after 1989 (1990-2010). To deliver insight for such long period, we have used mixed research methods. The first method is historical. We deliver historical facts, based on the discourse registered in print and online press.

The second method is national representative survey research, from which we provide declarative data. This method is also historical, because the research was conducted in 2010. Its context was the first Polish edition of World Internet Project (WIP), an international study on the Internet, to which we added questions on Polish Internet users' practices. Fieldwork was completed in May and June 2010. Computer-assisted personal interviews (CAPI) on representative random-quota took place in 2000 respondents' homes nationwide. The respondents were aged 15 years and older. According to the good practices in social sciences, the full questionnaire is available within the 2011 report from the project (WIP Questionnaire, 2011). 
Toczyski, Filiciak/Studies in Global Ethics and Global Education/ no 9/2018, pp. 60-77

\section{INSIGHTS ON DISCOURSE VERSUS PRACTICES. EXPLAINING PEER RE- PRODUCTION IN TERMS OF HISTORICAL EXPERIENCE}

In the discussed period of 1980-2010, despite the efforts of legislators and those involved in cultural industries, the informal economy in Poland is the primary media, rather than a marginal way, to access audiovisual content, especially since such practice at law were banned only since 1994, after the entry into force of the "Anti-Piracy Act".

We know from the literature that fan communities in non-democratic Poland under communism in the 1980s tended to access some cultural assets as a symbolic opposition to the state politics (Siuda, 2014). "Piracy" in the communist-socialist People's Republic (PRL, dated 1945-1989) has a long and interesting history, which does not respect the division between what belongs to the state or the regime, and what comes on a grassroots basis. Pirate was the "second circulation", in which translations of foreign books and copied cassettes of performances by bards of the "Solidarity" movement circulated. However, the party dignitaries also "pirated". We think that such phenomena related only to the entertainment, and as such, they are more universal. We can consider them in terms of peer re-production and an extended culture industry (Filiciak and Toczyski, 2014).

A good example of the universality of copying and redistribution practices are the practices associated with VHS recorders - Polish video boom of the 1980's was unique in the entire socialist camp. In 1984, Poland had about 70 thousand VCRs and three years later there were between 700 and 900 thousand VCRs. The official distribution of the cassettes was then about... twenty film titles. The circulation of unofficial content flourished, centered not on the "banned" production of political overtones, but primarily on the American popular culture and erotica. Present in Polish homes since the early 1980's, VCRs soon became a status symbol and a piece of equipment almost obligatory for Polish homes. After the fall of communism, leading up to the quasi-folk practices such as setting up a political VCRs' Holders Party, which, however, in contrast to the Polish Party of the Friends Beer similarly reflecting political pluralism of the beginning of the Third Republic, was not included in the Polish parliament. All of these devices were operated by copying the original material. Videos played using these devices were almost $100 \%$ provided by networks of selling and exchanging the copies with added amateur dubbing studios (except for content, there was also an important quality of the dubbing recording - the seller usually asserted that the offered copy was the "first copy"). The places of dissemination were organized in large cities at the weekly market, similar to the distribution of computer software and games. Interestingly, this mechanism was a faithful reflection of video content distribution among the Polish authorities of that period. The only difference was that the officials 
had benefited from institutional support as the Polish state TV special organizational cell was preparing non-disseminated officially recorded movies for party officials. Most copies were made of a demo material that was sent to the Polish TV by potential foreign partners.

Institutional and informal levels, moreover, mixed together at different levels. The bottom-up organized network of copying and distribution often took the form of companies, but also on this Eastern side of the Iron Curtain state institutions were sometimes a source of copyright-protected recordings. An example would be broadcast "Radiokomputer" in Scouts' Broadcasting (radio station belonging to the Polish Scouting Association), which from 1 July 1986 to the early 1990's broadcasted - for self-recording on cassette - software (utilities, educational and computer games) for Commodore, Atari and ZX Spectrum. The author of the broadcast, Tomasz Jordan, aired individual programs on the radio since 1984, of which he was writing in the computer magazine "Bajtek" (which was created in 1985 as a supplement to the "Youth Standard" with the support of his editor-in-chief Aleksander Kwasniewski, who later became Minister for Youth Affairs and after the change of system re-emerged as the Polish leftwing president). As some online sources say, Jordan wrote: "After the first issues, it turned out that the programs received in the ordinary range of radio receivers FM, recorded on tape, loaded up correctly to the computer (exactly about $70 \%$ ). So a new source of software was available to all comers throughout the country. We should add - which is available for FREE! This type of emissions, conducted by Scouts' Broadcasting, was the first in the socialist bloc countries" (Jordan, 1986).

Clearly, thinking in terms quite other than the infringement of intellectual property was dominant. The most developed, however, was a network associated with music market - not only on the radio (which often aired entire albums "to record" - radio DJs cared to make an appropriate long pause after their statements before the track would be released, and to not start talking until the last sounds), but also officially acting "recording studios", copying music to blank media for payment, and after the collapse of the People's Republic of street stalls selling copies of the tapes. They were universal phenomena - and it was the music industry at a time, moreover, after a breakthrough of 1989, which became the main opponent of these phenomena in a broad discussion of the "piracy".

The collapse of communist political system in 1989 was not only an important political breakthrough, but also a huge economic shock for Polish society. Reforms within the so called Balcerowicz Plan, named after the name of an academic economist and later finance minister professor, Leszek Balcerowicz, supported by Jeffrey Sachs' advisory services, offered Poles a "shock therapy", the critical recollection of which became the founding myth of the populist 
political groupings, and also recently upgraded from modern left-wing positions. Such therapy was also the case of culture - in the first years after the collapse of the system state radically reduced funding in this sector, which gave an impetus for the prosperity of the entertainment mainstream low-cost such as the simple and not ambitious music disco polo, a private television for mass and uneducated audiences and - which from the perspective of this text is particularly important - for industrial-scale piracy, in the consequence of which the Polish people had access to cheap pirated copies. However, because of pressure from the United States and Western Europe - exacerbated by the Polish West-oriented aspirations closely linked with the political objectives of joining NATO and the EU - Polish law was adapted to Western standards, and newspapers started writing about piracy as an index of backwardness of Polish civilization. Which is even clearer as the traditional media industry is based, after all, on the traditional model of respect for intellectual property.

The press and the entertainment industry, therefore, despite the so-constructed discourse defended their common interest. The discourse left no room for the acceptance of what for years - alongside state-supported cultural institutions - was an essential element in the content distribution in PRL. The largest Polish newspaper, Gazeta Wyborcza, published a series of texts devoted to piracy in 1990 - containing information about the pressure from the West, but also information about the release of the album "Breathless" by the singer Madonna in Poland (Soporek 1990). This was the first premiere, which was held in parallel with the world premiere on the Polish market, what was interpreted as proof that "we are chasing the world". Fighting piracy is described in the context of getting "maturity" of the music industry (the journalist even writes that our recording industry is facing "maturity exam").

Under the "normalization", numerous anti-piracy actions are held - including one of the biggest music festivals in Sopot, in 1991 entitled "Sing against the pirates" (KB, 1991). In 1992 in major Polish cities concerts in the series "Pirates are killing music" were organized (Brzozowicz and Chmiel, 1992). The press continues to educate the Poles, for whom "intellectual good" is still a fairly abstract concept.

The modernization discourse is reinforced by heavily emotional information about the dangers of the practice of piracy - the above mentioned Gazeta Wyborcza published, among others, in 1993, an article about holograms, allowing distinguishing the original from the pirated copies of the cassettes. Holograms are presented with a slight exaltation as a "certificate of morality" (Skawrońska 1993).

In 1994, the Parliament adopted a new law on copyright, the so called "Anti-Piracy Act". "For the first time in Poland under the statutory protection are to be found not only authors but 
also the producers and artists. In accordance with European standards, their rights will be protected for 50 years" - writes Gazeta Wyborcza on its frontpage (Dajbor, 1994). Soon after the introduction of the new law, an association of producers and publishers ZPAV reports that audiovisual piracy has dropped from 95\% to 40\% (Kowalski, 1994). In January 1995, prominent music critic and festival organizer Grzegorz Brzozowicz's summary of 1994 is titled 'Year of flowering phonographic", and in it the first year of existence "in Poland the music industry functioning according to healthy market principles" is mentioned (Brzozowicz, 1995).

The second half of the 1990s appears, however, to be a period in which piracy CDs flourished and "pirates caught a second wind". The situation radically changed thanks to Internet winning popularity - in the twenty-first century the gradual marginalization of "professional" piracy takes place, giving place to self-administered downloading content from the Internet. Today it is so widespread that, while earlier this downloading from the network was described by analogy to other practices (mainly theft), later it became a model to which others compare themselves.

In 2011, there were articles about the practice of reading comic books in a bookstore by young people, without subsequent buying the copy they read. Representatives of publishers compared that practice to Internet piracy. "Piracy" becomes thus the imaginary category for print publishers who reveal it by comparing unpaid reading to downloading - although ignorantly that this argument can be easily reversed (Wojtczuk, 2011; Czajka, 2011).

It should be noticed that in 2010, Poland was still cut off from many legitimate sources to access the content (range of platforms such as iTunes or Hulu did not include Poland). Their presence would not need to change the practice of "pirates" - but it is worth pointing out that the flourishing of piracy cultures can be regarded as a process in which citizens create their own grass-roots institutions for access to cultural content, because access is not provided to them by traditional institutions. It has developed its own mechanisms, including so called "subtitles scene", which consists of translators' groups working for free, preparing Polish subtitles for pirated copies of films downloaded from the Web. Moreover, the conflict between the subtitle translators and the company Gutek Film - one of the ambitious cinema distributors in Poland was a good opportunity to trace the bottom-up discourse associated with piracy.

In December 2005, the company sent a letter to the administrators of the two largest sites with subtitles - napisy.org and napisy.info - in which the violation of Gutek Film's rights to titles distributed by the company was stated (and thus, as has been claimed, their dialog paths). This led to suspension of activities of these sites (though napisy.info resumed its activity and functions to this day). The case went not only to court, but also to the biggest Polish newspaper columns, 
reflected on a wide coverage on the Internet. These voices are analyzed in the article on "subtitles scandal" (Hofmokl and Tarkowski, 2007). Authors distinguish the following arguments, largely representative of the general arguments for the pirate practices: high prices for the originals, but also malfunctioning industry, which introduces valuable productions in Poland with a long delay or not at all - and $\mathrm{p} 2 \mathrm{p}$ networks are the only way to access certain content. The distributing company was also an object of consumer complaints which stated that although self-advertised as a patron of culture, it is not company's ambition to expand the market for cinema in Poland, but to act solely for profit. Part of the Internet users presents anti-market demands, but also refers to the right of fair use. In short - around pirate practices there is still present a huge gap between the joint media and the traditionally (narrowly) defined cultural industries' perspective on the one hand, and the voices of ordinary citizens on the other hand.

\section{SURVEY RESEARCH RESULTS: POLISH PEER RE-PRODUCTION SPECIFICITY}

To explore the level of practices, a quantitative research process was designed that tested the theoretical model presented in the previous section. In 2010, we approached the first Polish edition of World Internet Project (WIP), an international study on the Internet, adding some questions on Polish Internet users' practices to the questionnaire. Fieldwork was completed in the Spring of 2010 and published widely. However, the items on alternative access to culture, which were not available in questionnaires applied in other countries were not covered extensively.

While working on the project covering 1980-2010, we decided to include a number of items meaningful for our emerging insights, providing data not available within other WIP countries. Data were collected within computer-assisted personal interviews. General methodological information about this quantitative study can be summarized as follows: representative random-quota sample of 2000 respondents, interviews conducted face-to-face in homes, with Poles aged 15 years and older, with one-month fieldwork timing (May and June, 2010). Such a sample and method allowed us to describe the key results in reference to the whole population of Poland. The full report from this research was published as grey literature (Toczyski et al., 2010), followed by the 2011 report containing the full 2010 WIP questionnaire with indicated 2011 amendments (Toczyski et. al, 2011). Some initial interpretations of the twoyear project results were highlighted as a supplement (Filiciak, 2011) to the full research report and as a separate discussion record (Toczyski and Ćwiklak, eds., 2011). 
Having referred the reader to the full context in which the data were collected, we will present only that part of 2010 results which is interesting as the historical snapshot of Polish internet users' attitudes at that time. Nearly half of Internet users in 2010 declared that they had downloaded files for free, mainly because they simply did not want to pay for them. One in five internet users said they paid for downloading various files, usually movies and music, whereas slightly less than half of them download files without paying. Non-paid downloading usually concerned music (a third of internet users downloaded music files for free), movies (a quarter downloaded them for free) and, to a lesser extent, games (downloaded for free by every tenth of internet users). Those who downloaded such pieces of content for free admit the main reason for doing so was to get them without paying, even though they could afford to pay for them. Less than a third claimed that they just wanted to have a try before buying. Less than a quarter said that they could not afford to purchase downloaded content legally. A few of these people said that they had no other possibility of access to content they downloaded. Older respondents were less likely to download files for free. Men were involved in downloading more often than women.

In broader perspective, time spent on other media consumption suggested that internet users in a typical week spent less time on the offline media activities than Internet non-users. Other media consumption included watching TV, listening to radio and (to lesser extent) reading the press. This is the general profile of internet users, which suggested a migration of content consumption online already at that time. The age profile of those spending more than 10 hours weekly on watching TV or using Internet may be concluded by a simple observation of the fact that media content consumption habits change. Among those aged under 30, more people spent 10 hours or more on using Internet than on watching TV.

The most popular type of entertainment on the Internet was simply surfing in the Internet - every second Internet user did it at least once a day. Nearly two thirds of Internet users used Internet to download or listen to the music and slightly fewer visited websites with short films, download or watch movies and play games. Radio was listened to by slightly less than half of Internet users. The type of entertainment looked for in the Internet analyzed by gender shows that men more often than women took advantage of various types of entertainment available on the Internet. The biggest differences between genders could be observed in the case of watching erotic websites and playing games. The key data was, however, the percentage of Internet users who replied otherwise than "never" to the question "How often do you use Internet in following purposes?" with regards to downloading music, which decreased as age increased. $86 \%$ of the youngest Internet users declared they downloaded music, whereas the oldest - aged 60 years or more - only $24 \%$. Downloading or watching online (streaming) movies, treated additively, was a 
similar type of activity: responses to the question about this source of entertainment were between $82 \%$ in the youngest group and $16 \%$ in the oldest group. In other words, the migration of entertainment content consumption towards online was especially the characteristics of young generation.

Broadly understood, the "creative" activities of Poles (using Internet for all the analyzed activities) decreased rapidly with age. The older respondents were, the chances were that they would post fewer comments, pictures, send music video or write a blog. However, active internet usage other than sharing and other than producing a piece of content "ever before" was rare. Only $6 \%$ of the respondents created some form of art (more often the youngest group), and it was predominantly a photographic piece - or pieces - of content. Only one quarter of those, who created something, did not post it in the Internet. Nearly all of those who posted a photo were amateur photographers, who posted it on social networking website. Copyright was not a big issue for those who posted the content on the Internet. According to their understanding of their rights to these pieces of content, the majority of this content was not copyrighted. Still, one in ten of those who had posted their work on the Internet claimed that someone had used it. Internet users did not have a precise attitude towards the use of the content they posted on the Web by others, but over one third stated that they would not like anyone to use it. For a quarter of them, it was acceptable, but with their permission. Thus, "creators", were faced with perceived copyright problems. Being only a "consumer" of the content did not seem to cause parallel perception problems.

Finally we approached the issue in a relatively direct manner, asking whether our respondents did happen to pay for different kinds of content or download it for free, in both cases at least from time to time. Men more often than women downloaded cultural content for free, especially music (37\% vs. $30 \%$ ), movies (30\% vs. $21 \%$ ), games (15\% vs. $7 \%$ ) and foreign TV series (6 vs. 3\%). The question with which this issue was approached, was "Do you happen at least from time to time to download for free such things as...", which we consider to be a good indicator of the problem. To counterweight the annoying issue, we also included the item "Do you happen at least from time to time to pay for an access in Internet to...”. One third of Internet users admitted to downloading music for free, one quarter of them - movies, and one tenth games. The main reason for downloading these pieces of content is no need to pay for them. Respondents admitted that they can afford it, but they take advantage of the possibility to have them for free. Only 15\% of Internet users paid for such things as music, movies, TV series (serials) when they downloaded them from the Web. The age structure of the discussed problem shows the prevalence of youth in free access to the culture. 
Free access is a phenomenon not only strictly legal and economic, but also of collective consciousness. Among the majority of Poles, regardless of age, opinion prevails that the anonymity of the Web leaves people unpunished as well as the statement that the violations of others' goods should be punished. These two almost criminal statements provide a summary of an interesting empirical illustration of the problem of "piracy". Although the content of these items of the questionnaire was not associated with downloading, its reading in the context of informal circulation of content still shows the belonging of downloading files and streaming as ways of acquisition of cultural content - or any "pieces of content" - to a different category in the collective consciousness. Regardless of age, the colloquial terms "goods" and "unpunished" seem to have little to do with intellectual property.

However, as yet another counterweight, the observation cannot be omitted - while presenting the snapshot of Poland in 2010 - that there still exist such pieces of content, which are not yet that much mentally as well as physically separated from the medium. The issue of access to such pieces of content, namely books, is worth considering through the prism of two questionnaire items: "Where do you get books from?" and "How many books read last year did you get from...?". Books are paid content rather than free, but even as such still show the importance of sharing ("I borrow from friends": $52 \%$ of those who claimed that they read at least one book during last year before the survey interview took place). Within digital, sharing of content is also the structural background of p2p networks. Readers usually used to get books by borrowing them from friends, buying in bookstores (Internet users more often than non-users) or borrowing from libraries (the most popular way of getting books among students - probably because they have access to school or university library). Only $6 \%$ of readers used to buy their books via Internet (among Internet users this figure slightly grew to 9\%) or in mail-order bookstore. At that time internet was not a common source of books, even for Internet users.

The percentage of those who got books from a particular source among internet users $(N=1316)$ shows that there are specific kinds of content, which were - in 2010 - still strictly attracted to the medium (print) and as such were more accessible in the traditional rather than digital form. 


\section{PRE-1989 ECOLOGY OF ACCESS TO AUDIOVISUAL CONTENT IN EUROPEAN SEMI-PERIPHERIES AS A FACTOR OF THE $21^{\text {ST }}$ CENTURY INFORMAL ECONOMY OF THE MEDIA}

Anecdotal evidence from the studies sponsored by manufacturers of equipment for broadband Internet service suggests that for many Internet users, a key argument to have a faster connection is "piracy". The complexity of the interdependence of the many actors in the Internet market is even higher, of course, with a more widespread introduction into discussion by providers of data transmission infrastructure - that is, especially telecoms - such an image of "value chain", from which the conclusion is that the current infrastructure is made available below the real cost, and the publishers are to receive a disproportionate amount of revenue from sharing their content.

From the standpoint of efficiency of distribution, piracy cultures can thus be regarded as a peculiar source of bottom-up innovation. Its sources are generally low-income countries, so treating piracy cultures as a source of innovation can overcome the imperialist scheme, under which the world center of innovation are mainly highly developed countries (as exemplified by the products "designed in USA, made in China"). At the level of the informal economy of the media it is not "old center" which is a place to create new solutions - it is in the old "peripheral" countries where the attitude to intellectual property is often different than in the United States and Western Europe. At the same time, the experience of recent years shows that in terms of cultural content exchange beyond traditional hierarchies and market access, it is not "old peripheries" that equal to the standards of "old center", but vice versa, young (and not so young) people from around the world are buying less and less and download more and more free content ("free" on their end) from the cultural network.

The accompanying discourse of piracy from 1989 to 2010 and beyond is relatively homogeneous. The top-down perspective dominates intended as the newspapers authors' and business consulting self-identification with manufacturers and distributors of content, imagined as deprived of money. There are no voices trying to justify the widespread piracy or to identify traditional practices that allow coping with the unavailability (not just economic) of cultural content. The gap between the media and everyday discourse, where piracy is absolutely accepted, is enormous. Our article provided an illustration of this specificity both in terms of historical experience and technological advancement. 


\section{REFERENCES}

All online links valid as of 15 May 2018

1. Benkler, Y. (2006). Wealth of the Networks. How Social Production Transforms Markets and Freedom. New Haven and London: Yale University Press.

2. Brzozowicz, G. and Chmiel, M. (1992). Piractwo z zasadami? Gazeta Wyborcza, 8 Jul 1992,.

3. Brzozowicz, G. (1995). Rok rozkwitającej fonografii. Gazeta Wyborcza Poznań, 5 Jan 1995.

4. Czajka, K. (2011). W sprawie oglądania komiksów. Gazeta Wyborcza Warszawa, 24 Jan 2011.

5. Dajbor, A. (1994). Piraci pod biczem. Gazeta Wyborcza, 6 Jan 1994.

6. Dukaj, J. (2009). Dylemat pajeczarza. Retrieved from http://ksiazki.wp.pl/tytul,Dylematpajeczarza,wid, 13348, felieton.html.

7. Filiciak, M. (2011). Instead summary: Informal Culture Circulation - The Scale and the Meaning. In: Toczyski, P., Kustra, A., Rzeźnik, J., Gerszewska, M. (2011). World Internet Project.

Poland 2011. Warsaw: Agora S.A. \& TP Group, https://depot.ceon.pl/handle/123456789/3639.

8. Filiciak, M. and Toczyski, P. (2014). Peer Re-Production and an Extended Culture Industry. The Case of TV Content and Redistribution in Europeanizing and Globalizing Poland. Studies in Global Ethics and Global Education / Studia z Etyki i Edukacji Globalnej, 1 (1), 117-135.

9. Hofmokl, J. \& Tarkowski, A. (2007). Piractwo ogranicza, piractwo wzbogaca życie kulturalne w Polsce. Analiza dyskursu na temat praw autorskich, rynku rozrywki i udziału w kulturze. In M. Burnecka \& R. Próchniak (Eds.), Dynamika kultury a (r)ewolucja wtasności intelektualnej, tom I (173-198). Wrocław: Atut.

10. Jordan, Tomasz (1986). Radiokomputer. Bajtek, 11, http:/ / emusearch.net/forum/viewtopic.php?t=15335\&sid=6718f3c9fa93e69b1535bff97 $316 a 66 a$

11. KB (1991). Zaśpiewać przeciw piratom, Gazeta Wyborcza, 24 Jul 1991. 
Toczyski, Filiciak/Studies in Global Ethics and Global Education/ no 9/2018, pp. 60-77

12. Kellner, D. (2009). Media Industries, Political Economy, and Media/Cultural Studies: An Articulation. In J. Holt \& A. Perren (Eds.). Media Industries. History, Theory, and Method (95107). Chichester: Wiley-Blackwell.

13. Kowalski, B. Producenci zadowoleni. Gazeta Wyborcza, 15 Jun 1994.

14. Lovink, G. \& Rossiter, N. (Eds.). (2007). MyCreativity Reader: A Critique of Creative Industries. Amsterdam: Institute of Network Cultures.

15. McGuigan, J. (1992). Cultural Populism. London: Routledge.

16. PWC (2014). Wplyw zjawiska piractwa medialnego na gospodarke Polski, https://www.pwc.pl/pl/biuro-prasowe/assets/pwc-polska-analiza-wplywu-piractwa-nagospodarke-prezentacja.pdf.

17. Rafael, V. (2003). The Cell Phone and the Crowd: Messianic Politics in the Contemporary Philippines. Public Culture 15(3), 399-425.

18. Raqs Media Collective (2010). Value and it's other in electronic culture: slave ships and pirate galleons. In Seepage (142-148), Sternberg Press: Berlin/New York.

19. Shastry, S. (2010). Internet piracy taking big toll on jobs. Retrieved from http://www.reuters.com/article/2010/03/17/us-eu-piracy-idUSTRE62G3BU20100317.

20. Siuda, P. (2014). In pursuit of pop culture: Reception of pop culture in the People's Republic of Poland as opposition to the political system - Example of the science fiction fandom. European Journal of Cultural Studies, 17(2), 187-208.

21. Skawrońska, J. (1993). Świadectwo moralności. Gazeta Stołeczna, 8 Oct 1993.

22. Soporek W. (1990). Gazeta Wyborcza [Piraci, 3 Feb 1990; Wideomania, 24 Feb 1990, ; 100 miliardów, 3 Mar 1990; IFPI w Polsce, 12 May 1990; Światowe premiery w Polsce, 26 May 1990].

23. Terranova, T. (2000), Free Labor: Producing Culture for the Digital Economy. Social Text, 63, Vol. 18, No. 2, 33-58.

24. Toczyski, P. and Ćwiklak D., eds. (2011). Polish Internet Users as Compared to the World: Where and Which Way is the Polish Internet Going? Warsaw: Agora, https://depot.ceon.pl/handle/123456789/3671.

25. Toczyski, P., Kustra, A., Rzeźnik, J., Gerszewska, M. (2010). World Internet Project. Poland 2010. Warsaw: Agora S.A. \& TP Group, https://depot.ceon.pl/handle/123456789/3857.

26. Toczyski, P., Kustra, A., Rzeźnik, J., Gerszewska, M. (2011). World Internet Project. Poland 2011. Warsaw: Agora S.A. \& TP Group, https://depot.ceon.pl/handle/123456789/3639.

27. TubeMogul (2010). YouTube's Top 100 By Type. Retrieved from http://www.tubemogul.com/research/report/31. 
Toczyski, Filiciak/Studies in Global Ethics and Global Education/ no 9/2018, pp. 60-77

28. Van der Sar, E. (2008). 50\% of All BitTorrent Downloads are TV-Shows. Retrieved from http://torrentfreak.com/50-percent-bittorrent-downloads-TV-080214.

29. WIP 2011 Questionnaire (2011). In: Toczyski, P., Kustra, A., Rzeźnik, J., Gerszewska, M. (2011). World Internet Project. Poland 2011. Warsaw: Agora S.A. \& TP Group, https://depot.ceon.pl/handle/123456789/3639.

30. Wojtczuk, M. (2011). Komiks spiratowany wzrokiem. Gazeta Wyborcza, Warszawa, 10 Jan 2011. 